POPE INNOCENT III AND THE MINORITY OF JAMES I

DAMIAN J. SMITH

University of Birmingham

(England)

\title{
CONTENTS
}

1. The Crisis in Aragon.- 2. The Legation of Peter of Benevento.- 3. The Cort at Lleida.- 4. Council at Montpellier and Arrival of Prince Louis.- 5. Worsening crisis in Aragon.- 6. The Fourth Lateran Council.- 7. The Toledan Primacy.- 8. The Dispossession of Raymond VI.- 9. The Reconciliation of the Montcada.- 10. The Protection of the Orphan King.

More than eight hundred years after the election of Lothair of Segni as Pope Innocent III (1198-1216), we may reflect that the Iberian Peninsula has been underrepresented in the voluminous literature that the most able of the medieval pontiffs has been subject to in the intervening centuries. While the papal letters to Portugal and those of the Vatican archives concerning Spain have been edited, there remains no edition of the Innocentian bulls in Spanish archives and regrettably few studies of the major ecclesiastical and political issues confronting Rome and the Peninsula at that time ${ }^{1}$.

'For the Spanish bulls, Demetrio MANSILla (Ed.), La documentación pontificia hasta Inocencio III (965-1216), Rome, 1955 [hereafter MDHI] and MANSILLA, La documentación española del Archivo Castel S. Angelo (395-1418), "Anthologica Annua", 6 (1958), pp. 285448; For Portugal, A. de Jesús DA CosTA and M.A. FERnANDES MARQues (Eds.), Bulário Portugués. Inocéncio III (1198-1216), Coimbra, 1989. Generally, on Innocent III, see James Powell, Innocent III: Vicar of Christ or Lord of the World?, Catholic University of America Press, 1994; Michele MacCarronne, Studi su Innocenzo III, Padua, 1972; Helmut RosciIer,

"Anuario de Estudios Medievales", 30/1 (2000) 
This article, studying the relationship between the Curia and AragonCatalonia during the early years of James I's minority (1213-1216), aims at going a small step further to remedying the second problem. Through the papal treatment of James I, we can add to our knowledge of the earliest years of the great Catalan ruler, and, most importantly, ask questions about the potentiality of pontifical power.

Until his defeat at the battle of Muret (12/9/1213), fighting on the side of heretics against the crusading army of Simon de Montfort, Peter II of Aragon (1196-1213) had been one of Pope Innocent's closest secular allies. Peter had been anointed at Rome and crowned by the Pope (11/11/1204), granted willingly the Libertas Ecclesioe (30/10/1207), protected Innocent's Staufer in Sicily through the marriage of his sister, Constance, to Frederick II (Autumn, 1209), defeated the Moors in the decisive battle of Las Navas de Tolosa (16/7/1212), and, indeed, legislated against heretics more severely than any other ruler of his time (in 1198 and $1204)^{2}$. His status at the Curia had grown commensurately with his power. But how would the Pope react, after Peter's death, towards a kingdom plunged into crisis, fallen from grace? If there was a 'potential' power inherent in the Apostolic See, if there existed an idea that the papacy felt

Papst Innocenz III und die Kreuzzüge, Göttingen, 1969; Christopher CHENEY, Innocent III and England, Stuttgart, 1976; Raymonde ForEVILLE, Innocent III et La France, Stuttgart, 1992; Werner MALECZEK, Papst und Kardinalskolleg von 1191 bis 1216, Vienna, 1984; Antonio OLIVER, Táctica de Propaganda y motivos literarios en las cartas antiheréticas de Inocencio III, Rome, 1957; Kenneth PENNINGTON, Pope and Bishops: the Papal Monarchy in the Twelfth and Thirteenth Centuries, Philadelphia, 1984; The most important studies of Innocent's relationship with the Iberian peninsula are MANSILla, Inocencio III y los reinos hispanos, "Anthologica Annua", 2 (1954), pp. 9-49; Bonifacio PALACIOS MARTÍn, La bula de Inocencio III y la coronación de los reyes de Aragón, "Hispania", 29 (1969), pp. 485-504, and, more directly, in the same author's, La coronación de los reyes de Aragón 1204-1410, Valencia, 1975; J.F. RIVERA, Personajes hispanos asistentes en 1215 al IV Concilio de Letrán, "Hispania Sacra", 4 (1951), pp. 335-55; J. GoÑI GAZTAMBIDE, Historia de la bula de la cruzada en España, Vitoria, 1958; Thomas BISSON, "Quanto personam tuam" (X2.24.18): its original significance, "Proceedings of the Fourth International Congress of Medieval Canon Law", 1976, pp. 229249; Achille LUCHAIRE, Innocent III: Les royautés vassales du Saint-Siège, Paris, 1908, pp. 157. Paul FREEDMAN has recently been publishing in "Römische Historische Mitteilungen" a series of letters he has discovered in Catalonian archives (reprinted in his Church, Law and Society in Catalonia, 900-1500, Variorum, 1994).

${ }^{2}$ On the relationship between Innocent III and Peter II, see Damian SMITH, Innocent III and Aragon-Catalonia: Studies in Papal Power, PHD thesis, University of Birmingham, 1997. especially Chs.2-4. On Peter II's reign generally, see Jordi Ventura SUBIRATS, Pere el Catòlic $i$ Simò de Montfort, Barcelona, 1960, and Enric BAGUÉ, Pere el Catòlic, in Els Primers ComtesReis: Ramon Berenguer IV, Alfons el Cast, Pere el Catolic, by Percy Schramm, Joan CABESTANY, Enric BAGUÉ, Barcelona, 1963, pp. 103-45. 
itself to be evolving towards a complete 'governance of mankind' ${ }^{3}$, never surely had there been a better opportunity to carry this conception to its outermost limits than with a thriving pontiff facing a severely weakened kingdom traditionally loyal to Rome. In short, how did the Vicarius Christi intend to use the plenitudo potestatis to re-shape mankind? And what could stop him from doing whatever he wanted to do? We address this subject.

\section{THE CRISIS IN ARAgON}

An explanation of the nature of the conflicts that would develop in the Crown during the minority of James is hampered by the lack of an exactly contemporary Aragonese or Catalan chronicle, but we are not entirely at a loss for information. In the Llibre dels feits, James, looking back to times he could barely have remembered but would have been informed of by those who did remember them (with their own biases, of course), certainly believed that both his uncle, Abbot Ferdinand of Montearagón, and his great-uncle, Count Sanç, had wished to snatch away the throne for themselves ${ }^{4}$. Ferdinand's actions from 1214, and the opportunities offered by Peter's own rejection of his marriage to Marie of Montpellier (casting suspicion on James's own legitimacy), do not leave him free from suspicion (and a religious had been king before), though nothing that Sanç does suggests that he aimed for more than control in the Minority government and vengeance for Peter's death ${ }^{5}$.

\footnotetext{
${ }^{3}$ See Brian TIERNEY, The continuity of Papal political theory in the Thirteenth Century: Some methodological considerations, "Mediæval Studies", 27 (1965), p. 242.

${ }^{4}$ JAUME I, Llibre dels Feits, ed. Ferran SOLDEVILA, Barcelona, 1982, [hereafter Llibre dels Feits], c. 11, p. 48; c. 14, p. 49; c. 18, p. 54. Donald KAGAY, The Line between Memoir and History: James I of Aragon and the Llibre del Feyts, "Mediterranean Historical Review", 11 (1996), pp. 165-176, has pointed to the account of the early years of James's life in his autobiography as one of the 'foggy patches', 'supplemented with tradition', in which the young ruler was inclined to see treachery everywhere, and, accepting this, we must certainly treat what James says with great caution.

${ }^{5}$ Arxiu de la Corona d'Aragó [hereafter ACA], perg. Pere I, no. 323, at the Treaty of Mallén (4 June, 1209), Peter had named his brothers Alfonso and Ferdinand as his heirs rather than James. See Ferran Soldevila, Vida de Jaume I el Conqueridor, Barcelona, 1969, pp. 201; On Ramiro the Monk, see especially F. BALAGUER SÁNCHEZ, Notas Documentales sobre el reinado de Ramiro II, "Estudios de la Edad Media de la Corona de Aragón", 3 (1947-8), pp. 29-54, and S. DE VAJAY, Ramire II le Moine, roi d'Aragon et Agnés de Poitou dans l'histoire et dans la légende, in Mélanges René Crozet, 2 vols, Paris, 1966, 2, pp. 727-50. The point about the validity of the marriage is made by G. ZURITA, Anales de la Corona de Aragón,
} 
But whatever their intentions, the Kingdom certainly split into factions. The Gesta Comitum Barcinonensium (this section of which may be near-contemporary) proclaimed that evils spread across the land and unheard-of confederations and conspiracies arose ${ }^{6}$, and what exactly contemporary evidence survives bears this out; in particular, Aragon itself (which had lost important nobles at Muret) ${ }^{7}$ was plunged into chaos. The economic situation certainly made matters worse. Sound financiers, like Guillem Durfort, had invested heavily in Peter's ambitions and now had to meet their obligations ${ }^{8}$. James was to recall that his father had pledged all his revenues to Jews and Saracens and had given away 700 knights fiefs (with only 130 remaining), and while Bisson's studies do not bear that out exactly, it seems certain that Aragon had suffered badly from the mortgage of the King's domains, and Catalonia far worse'. In the Crown's 'Wall

vol.2, annotated by A. Ubieto Arteta, M. Pérez Soler, L. Ballesteros Ballesteros, Valencia, 1967, [hereafter ZURITA], 2, p. 198. Also see, The Chronicle of San Juan de la Peña: a fourteenth-century official history of the Crown of Aragon, ed. and. trans. Lynn NELSON, University of Pennsylvania Press, 1991 [hereafter CSJPJ, c. 35, p. 61. The best justification of Sanç's actions as procurator comes in the splendid, though not always very reliable, article of Salvador SANPERE Y MiQuel, Minoría de Jaime I: vindicación del Procurador Conde Sancho: Años 1214-1219, "I Congreso de Historia de la Corona de Aragón", 2 vols, Barcelona, 1913, 2, 580-694. It should be read alongside Ferran Soldevila, Els Primers Temps de Jaume $I$, Barcelona, 1962. On the whole question of the succession to the throne in Aragon, see the excellent article of A. GARCía GALlo, El derecho de sucesión del trono en la Corona de Aragón, "Anuario de Historia del derecho español", 36 (1966), pp. 5-187.

${ }^{6}$ Gesta Comitum Barcinonensium, ed. L. Barrau Dihigo and J. Massó Torrents, Barcelona, 1925, [hereafter GCB], c. 27, p. 56; also Llibre dels Feits, c. 12, pp. 48-9; CSJP, c. 35, p. 61; S. SOBREQUÉS I VIDAL, Els Barons de Catalunya, Barcelona, 1957, p. 71; BISSON, Unheroed Pasts: History and Commemoration in South Frankland before the Albigensian Crusades, "Speculum", 65 (1990), pp. 306-7.

${ }^{7}$ La documentación pontificia de Honorio III (1216-1227), ed. D. MANSILLA, Rome, 1965 [hereafter MDHI], no. 34, p. 28; RODRIGO OF TOLEDO, Historia de rebvs Hispanie sive Historia Gothica, ed. J. FERnÁNDEZ VALVERDE, Corpus Christianorum Continuatio Medicevalis, 72 (1987) [hereafter DRH], Bk. VI, c. 4, p. 182; J. MIRET I SANS, Itinerario del rey Pedro I de Cataluña, II de Aragón, "Boletín de la Real Academia de Buenas Letras de Barcelona", 4, pp. 111-2.

${ }^{8}$ By 1212 , Peter certainly owed Guillem Durfort sixty thousand sueldos (Arxiu de la Catedral de Barcelona [hereafter ACB], 4-82-60). On Guillem, and others who contended with the fiscal problems during the minority, see Stephen BENSCH, Barcelona and Its Rulers, 10961291, Cambridge University Press, 1995, especially pp. 209-219; also, Fiscal Accounts of Catalonia under the Early Count-Kings (1151-1213), 2 vols, ed. T. BISSON, Berkeley, California, 1984 [hereafter $F A$ ], especially, 1, pp. 122-150.

${ }^{9}$ Llibre dels Feits, c. 11, p. 48; BISSON, The Finances of the Young James I (1213-1228), in his Medieval France and her Pyrenean Neighbours. Studies in Early Institutional History, Hambledon Press, 1989 [hereafter BISSON, Finances], pp. 351-391 (originally in "X CHCA", Zaragoza, 1980, 2, 161-208). 
Street Crash', powerful barons, such as Guillem de Montcada and Guillem de Cervera, secured financial control and jurisdictional rights over vast $\operatorname{areas}^{10}$. Moreover, it would seem that the Church in some areas had bankrupted itself in favour of the dead King, and factions had formed over the heresy question ${ }^{11}$. Worse still, Philip Augustus of France had his greedy eye focussed upon a seductively disgruntled Montpellier, Sancho VII of Navarre took the opportunity to fortify his frontier and extend his interests in Aragon, and the possibility of Castile or the Moors doing the same could not be dismissed ${ }^{12}$.

The initial insecurity post-Muret was aggravated by the unwelcome fact that the five-year old orphan King was in the hands of Montfort at Carcassonne. Soon after Muret an embassy to Montfort to demand the release of James met no success and, fearing that the Count would kill James, the nobles had had no choice but to have recourse to Innocent, sending envoys to Rome, with Bishop Hispan of Segorbe-Albarracín travelling at his personal expense ${ }^{13}$. In acting thus, the Crown had tacitly accepted that Innocent was the guardian of the young King and had the right to organize the government of the Kingdom during the minority.

Innocent already had three clear grounds on which to intervene: 1) in 1204, at Rome, Innocent had promised to protect Peter and his successors in return for fealty 2) the Vicarius Christi had an obligation to help miserabiles personce - a category which orphans most definitely came under - and to undertake business and legal affairs on their behalf 3) Marie of Montpellier, in her final will (20 April, 1213), had designated the Pope as custodian of James and it was the duty of every bishop to uphold the

\footnotetext{
${ }^{10}$ BisSON, Finances, passim.

"J. VINCKE, Staat und Kirche in Katalonien und Aragon während des Mittelalters, MünsterWestfalen, 1931, pp. 261, 264; Lawrence MCCRANK, The Frontier of the Spanish Reconquest and the Land acquisitions of the Cistercians of Poblet 1150-1276, "Analecta Cisterciensia", 29 (1973), p. 71.

${ }^{12}$ Léopold Delisle, Catalogue des Actes de Phillippe-Auguste, Paris, 1856, [hereafter DeLISLE], no. 1548, p. 352; Colección diplomática del Concejo de Zaragoza I. 1119-1276; II, 1276-85, ed. A. CANELlaS LóPEZ, Zaragoza, 1972-5, [hereafter $C D C Z$ ], 1, no. 45, p. 135; CSJP, c. 35 , p. 61 and note 242; Julio GONZÁLEZ, El reino de Castilla en la época de Alfonso VIII, 3 vols, Madrid, 1960, 1, p. 1072.

${ }^{13} M D H I$, no. 516, p. 556; $D R H$, Bk. VI, c. 5, p. $182 ; G C B$, c. 27 , p. 56 ; CSJP, c. 35 , p. 61; ZuRITA, 2, p. 197; BELPERRON, La Croisade contre les Albigeois et l'union du Languedoc à la France (1209-49), Paris, 1946, p. 286; VENTURA, Pere el Católic, pp. 233-4; M. ROQUEBERT, L'Épopée Cathare, 3 vols, Toulouse, 1970-1977, 2, p. 248.
} 
integrity of a testament ${ }^{14}$. So Innocent can establish his control through the 'special relationship' with Aragon re-affirmed in the Coronation of 1204, through those very broad-scoped 'exceptional cases' for involving himself in secular affairs, and through the requests made by the nobles of the crown themselves.

\section{The Legation of Peter of Benevento}

Innocent now fulfilled a promise he had previously made to Peter II in 1213 and sent a legate a latere for the affairs of Southern France and Aragon $^{15}$. To represent him, the Pope chose one of his closest and most trusted advisors, Peter Collivaccina of Benevento, cardinal deacon of Santa Maria in Aquiro. Cardinal Peter was a former Master of Bologna, who had been Innocent's chaplain and notary, had compiled the Compilatio III, the first official collection of decretals, and probably the biography of the Pope, the Gesta Innocentii ${ }^{16}$. Dated 17 January 1214 , Innocent sent a letter to all the bishops and clergy of the provinces of Embrun, Aix, Arles, and Narbonne. Innocent told them that since the local clergy had failed to restore orthodoxy to the region, Innocent was sending Peter, 'virum utrique litteratum, providum et honestum, quem inter cæteros fratres nostros specialis charitatis bracchiis amplexamur', who would reform the things that needed to be reformed and bring peace to the region. They were to treat the legate as if he were the Pope himself and fully and humbly observe all the instructions the Cardinal made ${ }^{17}$. In letters dated 20, 22, and 25 January 1214, Innocent instructed Cardinal Peter to enquire into Montfort's jurisdictional rights in the Viscounty of Nîmes, the possibilities of reconciling the Count of Comminges and the Viscount of Béarn, and the

\footnotetext{
${ }^{14}$ M. SheEhan, The Will in Medieval England, Toronto, 1963, p. 126.

${ }^{15} \mathrm{MDHI}$, no. 505, p. 549; Regesta Pontificum Romanorum inde ab anno 1198 ad annum 1304, ed. Augustus POTTHAST, 2 vols [hereafter vol 1 = POTTHAST], no. 4741; Patrologice latina cursus completus, ed. J-P. MIGNE, 221 vols, Paris, 1844-64 [hereafter MPL], vol. 216, col. 849 .

${ }^{16}$ MaleCZeK, Kardinalskolleg, pp. 172-174; James BRUndage, Medieval Canon Law, Longman, 1995, p. 195.

${ }^{17}$ PotThast, 4882; MPL, 216, 955; Recueil des historiens des Gaules et de la France, ed. M. BOUQUET and L. DELISLE, 25 vols, 1869-1904, [hereafter RHGF], 19, 587.
} 
reconciliation of the Toulousans respectively ${ }^{18}$. In a letter dated 23 January 1214, Innocent informed Montfort of Peter's imminent arrival, and ordered him to restore James, pointedly 'natum inclite recordationis Petri regis Aragonum', into his Kingdom so that his guardianship could be arranged. It would, Innocent said, be most unseemly if Montfort were now to hold James for any reason whatsoever (quoniam amodo indecens esset ut quacumque occassione natum retineres regis predicti), so he should personally give James into the hands of the legate who would care for him as seemed fitting; if Montfort did not do this, then Cardinal Peter would proceed against him in the manner that Innocent had instructed him to viva voce $e^{19}$. Given the punishments for those who abused the integrity of a testament, that should not have left too much to Simon's imagination ${ }^{20}$. It is also important to note here that Innocent was keen that the King should be submitted to the legate rather than to the nobles of the Crown. Cardinal Peter would be 'taking-over'.

As is well known Aragon's participation, in the military struggle in the Languedoc did not ceased with Muret. Montfort, pressing home his advantage, ravaged the County of Foix, and then went on a tour right into Provence, in order to quell rebellion, though at Narbonne, Montpellier, and Nîmes he faced large-scale hostility ${ }^{21}$. At Narbonne particularly, he had to vie for power in the duchy with Amalric himself ${ }^{22}$. The Catalans also continued to thwart him. In February 1214, to the delight of the poet Peire Cardenal, Baldwin, turncoat brother of Raymond VI, was captured, and

\footnotetext{
${ }^{18}$ (On Nîmes) PotThaST, 4886; MPL, 216, 958; RHGF, 19, 588. (On the Counts) PotThast, 4887; $M P L, 216,958 ; R H G F, 19,589$. (On Toulousans) PoTthast, 4890; $M P L$, 216, 959; RHGF, 19, 589 .

${ }^{19}$ 19. $M D H I$, no. 516, p. 556; POTTHAST, 4888; $M P L, 216,959 ; R H G F, 19,589$.

${ }^{20}$ SHEEHAN, The Will, pp. 123-4.

${ }^{21}$ PierRe DES VAUX-DE-CERnAY, Histoire Albigeoise, trans. Pascal Guebin and Henri MAISSONNEUVE, Paris, 1851 [hereafter Vaux-de-Cernay], chs. 487-90, pp. 187-88; ROQUEBERT, L'Épopée Cathare, 2, pp. 243-248.

${ }^{22}$ VAUX-DE-CERNAY, c. 492, pp. 188-9; Raymonde FOREVILLE, Arnaud Amalric, archevêque de Narbonne (1196-1225), in Narbonne. Archéologie et Histoire. Fédération historique du Languedoc méditerranéen et du Rousillon, Montpellier, 1973, pp. 133-4; Chanson de la Croisade Albigeoise, ed. Eugène MARTIN-CHABOT, 2 vols, Paris, 1931 [hereafter Chanson], 2, p. 67, note 2 (though the potential for quarrels over jurisdictional rights was certainly present when Amalric became Archbishop in 1212); However, ROQUEBERT, L'Épopée Cathare, 2, pp. 247-8, for co-operation between the two in the winter of 1213-4.
} 
executed by the Comte de Foix and the Catalan knight Bernat de Portella ${ }^{23}$. By the spring, near Narbonne, with the complicity of Viscount Aimery, a formidable array of nobles and clergymen of the Crown had assembled. Count Sanç, regent for Provence, and perhaps performing a similar task in Aragon, his son Nunyo Sanç, Hugues, Comte d'Ampurias, Guillem de Montcada, Guillem de Cardona, Dalmau de Creixell, Bishop Hispan, the archdeacon of Huesca, Guillem de Montrodon and Berenguer, Masters of the Templars and Hospitallers respectively, were ready to recover James by negotiation or war $^{24}$.

It was in these unpropitious circumstances that Cardinal Peter arrived in the South of France. From early April 1214, Peter 'pitched camp' in the archiepiscopal palace at Narbonne, having already concluded a truce between the crusaders and the Narbonnese. Then Peter called the Counts of Comminges and Foix and many others to his presence (the Viscount of Béarn was either very ill or already dead ${ }^{25}$. The inhabitants of Narbonne and Viscount Aimery swore to the legate that they condemned all heresy and its abettors, that they would do nothing to help those who wished to recover lands held by the crusaders with the approval of the Holy Roman Church, and would respect the Peace of the Church. Moreover, they swore that they would do nothing to retake the castles that Count Sanç and Nunyo Sanç had given to the legate as a sign of good faith, and would do nothing to attack King James of Aragon ${ }^{26}$. On 18 April 1214, the Counts of Comminges and Foix swore oaths in similar terms and made their submission to the Cardinallegate $^{27}$. Moreover, Peter ordered Montfort to come immediately to

\footnotetext{
${ }^{23}$ VauX-DE-CERnay, c. 495-500, pp. 189-192; Guillaume de PuYlaurens, Historia Albigensium, in RHGF, 19, [hereafter PUYLAURENS], c. 23, p. 209; VEnTURA, Pere el Catolic, p. 235 .

${ }^{2+}$ VAUX-DE-CERNAY, c. 501, p. 192; Llibre dels feits, c. 10, p. 47; ROQUEBERT, L'Épopée Cathare, 2, p. 252; Ventura, Pere el Catolic, p. 234. The names of the Aragonese can be ascertained from the witnesses to the various oaths sworn to the Cardinal-legate (see following footnotes)

${ }^{25}$ VAUX-DE-CERNAY, c. 503, p. 193; on the date of the death of Gasto de Montcada, see J. C. SHIDELER, A Medieval Catalan Noble Family: The Montcadas 1000-1230, University of California Press, 1983, pp. 134, 138 (note 105). It is regrettably not certain that Gastó was reconciled before his death.

${ }^{26}$ Histoire générale de Languedoc, ed. J. VAISSETE, 15 vols, Toulouse, 1872-93 [hereafter $H G L], 8$, p. 646; VAUX-DE-CERNAY, c. 503, p. 193.

${ }^{27} H G L, 8$, p. 643; Layettes du Trésor des Chartes, ed. Teulet and Delaborde, Paris, 1863, [hereafter Layettes], 1, no. 1068 (Foix) and no. 1069 (Comminges); VAUX-DE-CERNAY, c. 503, p. 193.
} 
Narbonne and to bring James with him. At Capestang, James was handed over to the legate ${ }^{28}$. By 25 April 1214, Peter was at Toulouse to receive the oaths of the consuls of Toulouse and, probably at this time, of Count Raymond VI himself ${ }^{29}$. Having achieved this, Peter departed to organize the government of the Crown of Aragon.

We lack any clear chronological report of Cardinal Peter's actions during the following months. Iberian historians have always agreed that Peter showed exceptional abilities ${ }^{30}$, and where he fell short in his success, we must certainly appreciate that the legate was subject to his limited knowledge of the area, the nature of the advice he received and the pressure put upon him by those who were around him. On entering Catalonia, Peter seems to have spent a considerable time in the diocese of Urgell reconciling suspected heretics, most notably Ramon de Josa ${ }^{31}$. Through a Jew called Isaac, Peter successfully and significantly negotiated a two-year truce with the Moors, and further insisted that Jews and Saracens, with whom Christian creditors possibly refinanced their loans after Muret, should answer for the King's debts before the master of the Templars ${ }^{32}$. We can also reasonably surmise that some time during the Summer of 1214, having sought advice from bishops, other churchmen, and influential laymen, with the threat of a dynastic break-up facing him, Peter sent messengers throughout Aragon and Catalonia to announce that a Cort would be held at Lleida, the most

${ }^{28}$ VAUX-DE-CERNAY, c. 506, p. 195; Llibre dels Feits, c. 10, p. 47; DRH, Bk. VI, c. 5, p. $182 ; G C B$, c. 27, p. $56 ; C S J P$, c. 35 , p. 61

${ }^{29}$ (Consuls of Toulouse) VAUX-DE-CERNAY, c. 507, p. 195; HGL, 8, p. 647; Layettes, 1 , no. 1072. (Raymond VI) $R H G F, 19$, p. 210.

${ }^{30} G C B$, c. 27 , p. 57 ; $C S J P$, c. 35 , p. 61; ZURITA, pp. 199-201; SOLDEVILA, Els primers temps, p. 85

${ }^{31} \mathrm{H}$. ZimmermanN, Die päpstliche Legation in der ersten Hälfte des 13. Jahrhunderts, Paderborn, 1913, pp. 44-5; Peter LINEHAN, The Spanish Church and the Papacy in the Thirteenth Century, Cambridge, 1971, p. 189; MIRET I SANS, Itinerari de Jaime I, Barcelona, 1908, p. 268; E. FORT I COGUL, Catalunya i la Inquisició, Barcelona, 1973, p. 54; $M D H$, no. 67, pp. 54-5, for confirmation by Honorius III (3/7/1217 of an agreement of $22 / 2 / 1216)$ in favour of Pietro Tusci of an annual rent of fifteen Barcelonan libras conceded by the bishop of Girona.

${ }^{32}$ ACA, Butlles, Innocent III, leg.3, no. 25; $M D H I$, no. 537, p. 568; SANPERE, Minoría de Jaime I, pp. 609-10; On Isaac, $M D H$, no. 310, p. 231; no. 311, p. 232; no. 315, p. 235. 
sensible location since it was a traditional seat of government and the one most central to the united realm ${ }^{33}$.

\section{THE CORT AT LLEIDA}

According to Zurita, who may have been working from information now lost to us, this Cort was held sometime before 15 August $1214^{34}$. The known list of participants is incomplete, and Aragonese in bias, but it appears that Abbot Ferdinand and Count Sanç, plus a vast array of barons, bishops or their representatives, and deputies of towns attended the Cort ${ }^{35}$. Peter certainly had a difficult balancing act to perform. Each sector of society intended to battle for its political prerogatives and financial security, and each encroached upon the ambitions of the others, and most importantly, upon the position of the King. The enactments of the Cort only survive concerning Catalonia 'usque Cincam' and it seems the measures were not simultaneously confirmed for Aragon $^{36}$. Cardinal Peter, by his own authority and in the name of James, 'Petri preclare memorie Regis Aragonum', imposed the Peace which the barons, soldiers, burghers and townsmen were ordered faithfully to observe. In the first eight articles, Peter gave the widest possible list imaginable of those people and things to be placed under the Peace, including among these the coinage of Barcelona. But some of the articles that followed were to be of even greater importance. Article 9 decreed that each town, with the advice of the diocesan bishop,

\footnotetext{
${ }^{33}$ Cortes de los Antiguos Reinos de Aragón y de Valencia y Principado de Cataluña (10641327). Cortes de Cataluña, 1, Madrid, 1896 [hereafter Cortes], pp. 90-1; Gener GonZalvo I Bou, Les Constitucions de Pau i treva de Catalunya (segles XI-XIII), Barcelona, 1994 [hereafter GoNZALVo], no. 23, p. 134; CSJP, c. 35, p. 61; Zurita, p. 199; Josep LlaDONOSA I PUJOL, Història de Lleida, 2 vols., Tàrrega, 1974-5, 1, p. 22; BENSCH, Barcelona and its Rulers, p. 42.

${ }^{34}$ ZURITA, pp. 199-200.

${ }^{35}$ Cortes, 1, pp. 90-1; Gonzalvo, p. 134; MIRET I SANS, Itinerari de Jaime I, pp. 19-20; SoldeVILA, Els Primers Temps, pp. 82-4 (published list of known participants), and pp. 71-5, discusses participants; James, in Llibre dels Feits, c. 11, p. 48, says that neither Ferdinand nor Sanç were at the Cort, a conviction that had no doubt grown out of the belief that they had been trying to steal his throne. ZURITA, pp. 199-200, follows James's account.

${ }^{36}$ Cortes, 1, pp. 90-91; GonZalvo, no.23, p. 134; ACA, Butlles, Innocent III, leg.3, no. 25; $M D H I$, no. 537, p. 568: 'Pax autem a cardinali iam dicto facta in Cathalonia et statuta inviolabiliter observetur'. This would certainly suggest that the Peace at least did not apply to Aragon.
} 
was to elect two paers, or peace-men, one of the greater and one of the lesser citizens. Likewise, the procurator was to name a Catalan vicar for each town. These men were to play the central part in upholding the Peace. Article 13 stated that those who adamantly continued in private quarrels could be excluded from the Peace by the vicar or the paers, and excommunicated by the bishop. Also excluded from the Peace were all manifest heretics, robbers and their abettors. Article 14 placed outside the Peace and subject to financial penalties all those who attacked the upholders of the Peace. A significant number of the later articles dealt with financial problems. Article 17 revoked all 'pedagia' or 'leude' exacted by Peter II, while Article 20 provided that no new taxes were to be introduced until James reached the age of puberty, though articles 15, 16, and 20 all in some part were means of encouraging voluntary subsidies for the redemption of the King's pledges. Article 19 was particularly innovative. It declared that all lay men of fourteen or more years must affirm the Peace under oath and anyone who refused to do so was to be placed outside the Peace and suffer the consequent temporal and spiritual punishments. Article 21 declared that the Peace was to be observed for three years and could only be revoked by a mandate of the Cardinal legate or the Pope ${ }^{37}$.

Peter had taken care to respond to ecclesiastical and urban fears of baronial revolt. Moreover, in Article 9, he had recognised the enthusiastic renewal of those municipal initiatives that had been such a prominent feature of the early years of Peter II's reign. But there he had also noted the barons' desire for a vicar who was a Catalan, and his financial concessions were designed to avoid just those revolts that had beset the Crown for the last decade. Of course, his actions could be criticised. He had left a considerable amount of power in the hands of a regent who was not universally trusted; in avoiding general taxation, he left the Crown the prospect of a precarious economic future; as the Aragonese did not swear the Peace, then he may further have 'aggravated partisanship'38. But any criticism must be tempered by the extraordinary difficulty of the situation, and the remarkable conclusion to the Cort. It seems that it was now that Cardinal Peter declared Sanç as the procurator and issued him his written instructions on the manner

\footnotetext{
${ }^{37}$ Cortes, 1, pp. 91-5; GonZalvo, no. 23, pp. 134-141; Soldevila, Primers Temps, pp.789; SANPERE, Minoría de Jaime I, pp. 600-4.

${ }^{38}$ Thomas BISSON, The Medieval Crown of Aragon, Oxford, 1986, p. 59; SHIDELER, Montcadas, p. 138; Bisson, Finances, pp. 354-5.
} 
in which to carry out his office ${ }^{39}$. In an unprecedented move, the Cardinal called upon all those present from both realms to swear fealty to the King. The scene at the palace at Lleida could not have been more dramatic. Not only was the Cardinal demanding of the company their loyalty to a weak and helpless little orphan, but also to preserve the dynasty he was binding Aragon and Catalonia together in spiritual union through an elevated and exhilarating ritual. James was six. Probably the massed throng could not see him. His maternal uncle, Espàreg, Bishop of Pamplona, took the King in his arms and held him aloft. Everybody swore the oath and then departed from the $\operatorname{Cort}^{40}$.

\section{Council at Montpellier and Arrival of Prince Louis}

By the terms of Marie of Montpellier's first will, James was now given into the care of Guillem de Montrodon, the Master of the Templars. Guillem returned the King and Count Ramon Berenguer V of Provence to the Templar fortress of Monzón, on the border between Aragon and Catalonia, a place that would not leave James with fond memories ${ }^{41}$. During the last months of the year, Cardinal Peter probably dealt with arguments that came to his own court and settled (as far as he could)

${ }^{39} G C B$, c. 27 , p. 56; That Cardinal Peter gave to Sanç written instructions on how his commission was to be carried out is confirmed by the rubric of 1216, (Theiner, Vetera monumenta Slavorum meridionalium historiam illustrantia, ed. A. THEINER, Rome, 1863) [hereafter THEINER], 70, no. 211; POTTHAST 5314; $M D H I$, no. 565, p. 583); ZURITA, p. 201. $C S J P$, c. 35 , p. 61 , seems to place the beginning of the Procuratorship through an assembly at Monzón, possibly drawing on Llibre dels Feits, c. 10, p. 47.

${ }^{40}$ Llibre dels Feits, c. 11, p. 48; On Espàreg, see D. CABRÉ, Spàreg de la Barca, Arquebisbe de Tarragona, "XII.CHCA", Montpellier, 1988, pp. 57-70, and the contrary view of LiNEIAN, Spanish Church, pp. 35-6. Exactly when Espàreg was transferred from Pamplona to Tarragona is not clear, though it was after these events; The clergy and people of Tarragona sought confirmation from Innocent of his election in February 1215 (MDHI, no. 517, p. 556; J. Villanueva, Viage literario a las iglesias de España, 22 vols, Madrid, 1803-52 [hereafter $V L], 19$, pp. 224-6). His predecessor, Ramon de Rocabertí, died on 6 January, 1215 (VL, 19 , p. 175). See also, Jose GoÑ GazTAmBide, Historia de los Obispos de Pamplona s. IV-XIII, Pamplona, 1979, pp. 540-544.

${ }^{41}$ Llibre dels Feits, c. 10, P. 47; GCB, c. 27, p. 56; see J. M. LACARRA and L.GonZÁLEZ AnTón, Les Testaments de la Reine Marie de Montpellier, "Annales du Midi”, 90 (1978), p. 113. 
disputes concerning the repartimiento of 'honores' in Aragon $^{42}$, before returning to the South of France. The legate's actions at Narbonne in the previous April had both conflicted with and aided Montfort's ambitions. Peter had thwarted Simon by reconciling his greatest enemies but he had also obtained their guarantees not to attack the crusade. This gave Montfort relatively little opposition in securing his authority in his now considerable domains. After Peter's departure, from May to November 1214, the Count launched a devastating expedition through Quercy, Agenais, Périgord, and Rouergue $^{43}$. With the support of a new legate, Cardinal Robert de Courçon, and many of the higher clergy, Montfort received the submission of many of the leading nobles of the area, and was ceded the Viscounties of Agde and Nîmes by Bernard Aton ${ }^{44}$. On 7 December, Cardinal Robert, who, not always with great popularity, was conducting a series of councils as a prelude to Lateran IV, wrote to Arnaud Amalric, convoking a great council at Montpellier, to deal with matters of ecclesiastical discipline and to bring to a successful conclusion the Holy affair of Christ against the heretics ${ }^{45}$.

Cardinal Peter had returned in time to watch over the council. It met on 8 January 1215 , in the Church of Notre-Dame-des-Tables ${ }^{46}$. The archbishops of Narbonne, Auch, Embrun, Arles and Aix, twenty-eight bishops, numerous abbots, and many leading laymen attended. Thirty canons were promulgated concerning the reform of the Church and the destruction of heresy ${ }^{47}$. Afterwards, the 'political' question was dealt with. According to Vaux-de-Cernay, Peter demanded of the prelates, in the name of Divine Judgement and the obedience they owed to the Holy Roman Church, that

\footnotetext{
${ }^{42}$ See Cortes, 1, c. 7, p. 91; Gonzalvo, no. 23, p. 135; ACA, Butlles, Innocent III, leg.3, no. 25; SANPERE, Minoría de Jaime I, pp. 609-610. 96.

${ }^{43}$ VAUX-DE-CERnAY, chs. 513-41, pp. 197-206; ROQUEBERT, L'Épopée Cathare, 2, pp. $265-$

${ }^{44}$ VAUX-DE-CERNAY, chs. 513-41, pp. 197-206; see Catalogue des actes de Simon de Montfort, ed. A. MoLINIER, Paris, 1873, [hereafter MoliniER], nos. 79-94; (cession by Bernard Aton) Molinier, no. 79; $H G L, 8$, p. 651; (Charter of Robert de Courçon in favour of Montfort) MOLINIER, no. 85; $H G L, 8$, p. 653.

${ }^{45}$ Sacrorum conciliorum nova et amplissima collectio, ed. G.D. MANSI, 31 vols, Florence, 1759-98, [hereafter MANSI], 22, p. 950-1; Marcel and Christine DICKSON, Le Cardinal Robert de Courçon: Sa vie, "Archives d'histoire doctrinale et littéraire du moyen âge", 9 (1934), pp. 53-142; J.W. BALDWIN, Masters, Princes and Merchants: The Social Views of Peter the Chanter and his Circle, 2 vols, Princeton University Press, 1970, 1, p. 311.

${ }^{46}$ MANSI, 22, pp. 935-954; VAUX-DE-CERNAY, c. 543, p. 207.

${ }^{47}$ MANSI, 22, pp. 935-54; VAUX-DE-CERNAY, c. 543, p. 207; ROQUEBERT, L'Épopée Cathare, 2, pp. 297-301; VenTuRA, Pere el Catòlic, pp. 239-43.
} 
they should advise him faithfully, and without fear or hatred, as to whom, for the honour of God and the Holy Church, for the peace of the Country and the ruin of heresy, it was necessary to assign the domains of the Count of Toulouse and the other lands conquered by the crusaders. After much deliberation the prelates unanimously responded that Montfort should be 'princeps et monarcha' (though not monarch in our sense) of all these lands, and demanded that Peter grant them to the Count. Cardinal Peter, conscious of the limits of the legatine power, refused to do this, since, as he said, it had not been part of the commission Innocent had entrusted to him. The council accepted this, but, with Peter's approval, sent Archbishop Bernard of Embrun to Rome to explain their decisions to Innocent and request that he respond favourably ${ }^{48}$. Peter, emphasising the nature of his authority, fulfilled what had been decided at Narbonne in the previous April, and entrusted the castle of Foix to the abbot of Saint-Thibery and sent Bishop Foulques of Toulouse to take possession of the Château Narbonnais in the name of the Church $^{49}$.

While in a letter dated 4 February 1215 , in response to an embassy from a near penniless Raymond VI, Innocent delayed the final decision on the ownership of the lands until it could be more expertly and fully discussed in the General Council ${ }^{50}$, in a series of letters dated 2 April, Innocent awarded the conquered lands temporarily to Montfort, saving only the County of Melgueil, under the protection of the Holy See from 1085, that was ceded to the bishop of Maguelonne in return for an annual census of 20 marks ${ }^{51}$. Montfort acted as if for surety, while Philip Augustus, with his hands free after the defeat of the Anglo-German-Flemish alliance at Bouvines, finally decided to send Prince Louis with a powerful army into the South, perhaps to check his vassal and certainly to secure the Crown's rights

\footnotetext{
${ }^{48}$ VAUX-DE-CERNAY, chs. 545-7, pp. 207-8; on the word 'monarcha' to mean the unique ruler, see Paul GuÉBIN, Sur le sens du mot 'monarcha' au concile de Montpellier, "Revue historique de droit française et étranger", (1931), pp. 417-8.

${ }^{49}$ Puylaurens, c. 24, pp. 210; VauX-DE-Cernay, c. 549, p. 209.

${ }^{50}$ PotTHAST, 4950; Layettes, 1, no. 1099.

${ }^{51}$ POTTHAST, 4967; MANSI, 22, 937; Layettes, 1, no. 1114; VAUX-DE-CERNAY, chs. 554-9, pp. 211-2. On Maguelonne, see Potthast, 4972, and Johannes FRIED, Der Päpstliche Schutz für Laienfürsten: Die politische Geschichte des päpstlichen Schutzprivilegs für Laien (ll.-13.Jh.), Heidelberg, 1980, pp. 153-184.
} 
over territories that the crusade had, of course, unwelcomely seized in the name of the Pope ${ }^{52}$.

Cardinal Peter regarded Louis' appearance with a cold eye, unsurprisingly given the French Crown's reluctance to intervene in the past, and demanded assurances (which the Prince gave) that his decisions would not be contravened ${ }^{53}$. A particular worry concerned Montpellier. In January 1214, fearful of the excesses of Montfort, and for a long time without a ruler, the Montpellerians sent messengers to Philip Augustus, who, attracted by the economic, strategic and intellectual importance of the town, placed it under his protection for five years, promising to preserve its ancient customs, and to continue his protection even if Innocent designated James as heir to the seigneurie. The tie, however, would be broken if the Cardinallegate ordered Louis to take the town in the crusade ${ }^{54}$. The Montpellerians also sent a request to Innocent for his protection, which he granted on 10 April in return for an annual census of two gold marks ${ }^{55}$. Dated 15 April 1215 , Innocent wrote to Louis to congratulate him on taking the Cross but also to warn him clear of attacking Montpellier which Innocent declared was the possession of James ${ }^{56}$.

\section{WORSENING CRISIS IN ARAGON}

This must have been only small consolation for Count Sanç and the party within the Crown who were determined to continue the struggle, who must have viewed these events with trepidation. The Languedoc seemed to be slipping away and Provence too. In one significant step, Sanç arranged the marriage of Peronella, widow of the Viscount of Béarn, to his own son

\footnotetext{
${ }^{52}$ VAUX-DE-CERnay, c. 550, p. 209; RoQUeBert, L'Épopée Cathare, 2, pp. 313-5; VENTURA, Pere el Catòlic, pp. 244-7.

${ }^{53}$ VAUX-DE-CERNAY, c. 552, p. 210; RoQUEBERT, L'Épopée Cathare, 2, p. 318; VENTURA, Pere el Catòlic, p. 245.

${ }^{54}$ DeLISLE, no. $1548 ; H G L, 8$, p. $642 ; R H G F, 19,607$. The dates of the embassy to Philip and of his charter are discussed in ROQUEBERT, L'Épopée Cathare, 2, pp. 316, 440.

${ }^{55}$ RoQuebert, L'Épopée Cathare, 2, p. 317.

${ }^{56}$ Cartulaire de Maguelonne, ed. J. RouQuetTE and A. VILLEMAGNe, 2 vols, Montpellier, 1913-14 [hereafter ROUQUETTE], 1, p. 377; ROQUEBERT, L'Épopée Cathare, 2, p. 317.
} 
Nunyo Sanç ${ }^{57}$. With Gastó de Béarn's death in 1214, the Counties of Béarn and Bigorra were split, with Peronella retaining the latter. Sanç feared (quite correctly) that Montfort would force the widow into a marriage whereby he could take the County ${ }^{58}$. To protect Béarn, Sanç allied himself with the unrequited assassin, Guillem Ramon de Montcada, who had returned to his homeland to claim his inheritance ${ }^{59}$. If these efforts seem only slight and negative, it must be recalled that the internal situation of the Crown was still very grim. While the Templars ably sought to recover the royal domain, without general taxation the coffers remained almost empty ${ }^{60}$. James was to recall that on arriving at Monzón he had even had to go a day without food, 'so pledged and wasted was the land' ${ }^{61}$. Worse still, many of the barons and ecclesiastics did not share Sanç's view of what the political direction should be, did not wish to continue the war, held no confidence in his handling of affairs, and resented the extensive administrative and political power he had been given ${ }^{62}$. In Aragon, there were uprisings at Huesca, Jaca, and Zaragoza, seemingly nurtured by Abbot Ferdinand, who was clearly not alone in his efforts to discredit Sanç and withdraw allegiance from James ${ }^{63}$. Count Sanç had no realistic choice but to secure as many allies as he could within the realm, and to have recourse to the Pope (who was not universally popular either $)^{64}$. On 10 September 1215 , at a parliament at Huesca, it was decided that two ambassadors, Guillem de Cervera and Pedro Ahones, should be sent to the General Council, and,

\footnotetext{
${ }^{57}$ ACA, perg. Jaume I, no. 26; SoldevilA, Els Primers Temps, pp. 101-2; ShIDELER, Montcadas, p. 139.

${ }^{58}$ The original agreement of marriage and union between the Counties can be found in Liber Feudorum Maior, ed. F. Miouel Rosell, 2 vols, Barcelona, 1945-7 [hereafter $L F M$ ], 1, no. 21 , pp. 29-31; on the marriage with Nunyo Sanç and the subsequent separation and betrothal of Peronella to Montfort's son, see ACA, perg. Jaume I, no. 26; $H G L, 6$, p. 498; SHIDELER, Montcadas, pp. 139, 142; RoQuebert, L'Epopée Cathare, 2, pp. 261, 436-7; VenTURA, Pere el Catòlic, pp. 248-9, 278.

${ }^{59} \mathrm{ACA}$, perg. Jaume I, no. 26; Pierre de MARCA, Histoire de Béarn, Paris, 1640, pp. 5356; SHIDELeR, Montcadas, p. 139; Ventura, Pere el Catòlic, pp. 248-9.

${ }^{60}$ BISSON, Finances, passim; ACA, perg. Jaume I, no. 147.

${ }^{61}$ Llibre dels Feits, c. 11, p. 48.

${ }^{62}$ Shideler, Montcadas, pp. 141-2; Llibre dels Feits, c. 12, pp. 48-9.

${ }^{63}$ Palacios Martín, La coronación, pp. 302-3; El Libro de la Cadena del Concejo de Jaca, ed. Dámaso SANGORRín, Zaragoza, 1979, nos. 25-7, pp. 279-294; CDCZ, no. 44, p. 134.

${ }^{64} \mathrm{BENSCH}$, Barcelona and its Rulers, pp. 201-2, has pointed to Arnau Adarró's insistence on claiming interest on a debt in ACB I-6-1044: "non in hoc obstante iure vel precepto quod sit factum vel faciendum a domino papa et omni alio iure divino et humano'.
} 
along with Bishop Hispan, should discuss at the Curia business relating to the dead King Peter and other matters concerning his successor. The wretchedness of Sanç's situation is indicated by the fact that he had to promise Guillem and Pedro that he would pay all their expenses for the trip $^{65}$.

\section{The Fourth LATERAN COUNCIL}

Bishop Hispan, Pedro Ahones, and Guillem de Cervera now set off for Rome, and probably travelling with them was Guillem Ramon de Montcada $^{66}$. The Iberian contingent at the Council was impressive. From the province of Tarragona came Archbishop Espàreg, and the bishops of Gerona, Barcelona, Vic, and Calahorra. In all from the Iberian provinces, there were twenty-three bishops, plus the bishops of the three exempt sees (León, Burgos, and Oviedo) ${ }^{67}$. With their retinues, and taking into account the number of little-known abbots who might have attended, one can safely say there was an unprecedentedly large Peninsular presence ${ }^{68}$. This attendance, however, must be seen in the context of the Council as a whole. In all, the cardinals, patriarchs, archbishops and bishops participating numbered four hundred and two, and the abbots and priors around eight

\footnotetext{
${ }^{65}$ Colección de Documentos Inéditos del Archivo de la Corona de Aragón, ed. P. DE BofARULL Y MASCARÓ, Barcelona, 1847-1910, [hereafter CDIACA], 6, pp. 78-9; ACB, Libri Antiquitatem, IV, f. 218, 497 (MAS, 2588), would suggest that in January 1216 Bishop Berenguer of Barcelona was equally conscious of the expenses of his journey to Rome, when in a donation to Sant Cugat he reserved the right to moderate questie in two possible instances: 'preterquam in duobus casibus scilicet si personaliter oportet nos ire in expeditione in Hispanie vel Romam ire pro facto ecclesie nostre'.

${ }^{66}$ Ventura, Pere el Catòlic, pp. 249-50, insists on Guillem de Cervera negotiating in the Pyrenees in November 1215, but the events he refers to were of the previous year. See MARCA, Histoire de Béarn, pp. 535-6; SHIDELER, Montcadas, p. 139.

${ }^{67}$ There are twenty-six Iberian bishops reported in the Zurich MS. compared with sixteen certainties in those of Toledo (the absences in these MSS, as we shall say, are significant). On the Iberian attendance at the Council, see the fine article of J.F. RIVERA, Personajes Hispanos Asistentes en I215 al IV Concilio de Letran, "Hispania Sacra", 4 (1951), pp.335-355, with the table of pp.347-8.

${ }^{68}$ Taken as a whole, this is so, though one can say, for instance, that the attendance from the Province of Tarragona at Alexander III'S Council at Tours in 1163 was substantially larger. See Robert Somerville, Pope Alexander III and the Council of Tours (1163): A Study of Ecclesiastical Politics and Institutions in the Twelfth Century, University of California Press, 1977, p. 28.
} 
hundred. Moreover, there were representatives of other religious orders and a significant quantity of notable laymen, and delegates of towns, cities, nobles, and kings ${ }^{69}$. Italy, of course, predominated, but the still tangible feeling of those who were there was of the sheer vastness of the assembly. As the Giessen text put it, 'No eye has seen, nor ear heard, nor the heart of man conceived so many different languages, so many ranks of distinguished people, from every nation which is under heaven, who have gathered at present at the Apostolic see: Parthians and Medes and Elamites, with those who dwell at Jerusalem, ${ }^{70}$.

That is what Innocent III wanted everybody to think. The Fourth Lateran Council was a show, 'a show with a meaning"71. All its events, from the procession at Trastevere to the veneration of the Living Wood of the True Cross, even (one suspects) the pointed papal walk-out on 20 November when the imperial question raised its ugly head, were shrewdly staged by the Pontiff'. Similarly, though in 'Vineam Domini Sabaoth', of 19 April 1213, opportunity had been given for bishops to report on what needed reform in their dioceses, the Constitutions of the Council were almost entirely the work of Innocent and the Curia, undebated and uncontested ${ }^{73}$. Innocent drew up the programme; Innocent presided; Innocent directed. A pope preparing for the end of time and for his own end, this was to be the culminating moment of his life, where his profound contemplation on the theological, liturgical, and canonistic questions that faced the Church would allow him to impose upon the Church as a whole solutions whereby the evils in Christianity would be corrected and, hence, the Holy Land could be recovered. And that meant the Church in the broad sense. The Council, Maccarronne lamented, spent its time wrangling over political disputes ${ }^{74}$.

\footnotetext{
${ }^{69}$ Raymonde Foreville, Latran I, II, III et Latran IV, Paris, 1965, pp. 391-5.

${ }^{70}$ Stephan KutTNER and Antonio García y García, A New Eyewitness Account of the Fourth Lateran Council, "Traditio", 20 (1964) [hereafter New Eyewitness], p. 123.

${ }^{71}$ The phrase belongs to Brenda BoLTON, A show with a meaning: Innocent III's approach to the Fourth Lateran Council, 1215, "Medieval History", 1 (1991), pp. 53-67.

${ }^{72}$ New Eyewitness, pp. 125, 143 (on Trastevere); pp. 128-9, p. 166 (on adoration of the Cross); pp. 125-6, 147-8 (on Empire).

${ }^{73} M D H I$, no. 503, pp. 543-5; MPL, 216, 823; POTTHAST, 4706. On Innocent's own initiative for the Conciliar acts, see MACCARRONNE, Il IV Concilio Lateranense "Divinitas", 2 (1961), pp. 270-298; GARCÍA Y GARCíA, El Concilio IV de Letrán (1215) y sus comentarios, "Traditio", 14 (1958), pp. 484-502; GARCÍA Y GARCíA, El gobierno de la Iglesia Universal en el Concilio IV Lateranense de 1215, "Annuarium Historiæ Conciliorum", 1 (1969), pp. 50-68.

${ }^{74}$ MacCARRonNE, Il IV Concilio Lateranense, pp. 279-80.
} 
But there were no 'political' disputes. Rome and Peter united all 'for the honour and glory of the Divine Name, for the healing and salvation of souls, and the good and benefit of the Christian people ${ }^{75}$.

\section{The TOlEDAN PRIMACY}

The Council was liturgically divided into three solemn sessions ${ }^{76}$. Both of the debates that were most of interest to Aragon were in the first session. On Friday, 13 November, the Primacy of Toledo was debated ${ }^{77}$. The claim of Toledo to primacy was, of course, based upon its pre-eminence in the Visigothic period. It had been the seat of the national councils, the royal see, and from 681 had held its characteristic rights in the election, examination, and consecration of the bishops of the metropolitan sees. After Alfonso VI restored the see in 1086, Toledo sought to revive its rights. From the second quarter of the Twelfth Century, Tarragona, Braga, and Compostela progressively ignored the resurgence of the Visigothic edifice and insisted Toledo had no juridical influence ${ }^{78}$. In this, their respective secular rulers supported them. Recognition of Toledan primatial rights was tantamount to recognition of Castile's imperialistic claims. Submission to the influential and powerful prelate in Toledo was conditioned by the state of a kingdom's fortunes in relation to Castile. In the last quarter of the Twelfth Century the consolidation of the other Hispanic kingdoms led to an ever more comfortable disregard of the 'foreign' bishop ${ }^{79}$. The Papacy, between 1088 and 1192 , willingly ratified the primatial dignity of Toledo on certainly fifteen occasions. The archbishops of Tarragona in particular faced some

\footnotetext{
${ }^{75} M D H I$, no. 503, p. 544; MPL, 216, 823; POTTHAST, 4706: 'ad laudem et gloriam nominis eius, remedium et salutem animarum vestrarum ac profectum et utilitatem populi christiani'.

${ }^{76}$ Foreville, Procédure et débats dans les conciles médiévaux du Latran (1123-1215), "Rivista di Storia della Chiesa in Italia", 19 (1965), p. 29; GARCíA Y GARCíA, El gobierno de la Iglesia Universal, pp. 52-3, has a very useful table of events.

${ }^{77}$ New Eyewitness, p. 124; GARCíA Y GARCía, El gobierno de la Iglesia Universal, pp. 52-3.

${ }^{78}$ The bibliography on this subject is very vast indeed, but see Peter LINEHAN, History and the Historians, which concentrates much attention on the history of Toledo; RIVERA, La iglesia de Toledo en el siglo XII (1086-1208), 2 vols, Rome, 1966; Toledo, 1976; RIVERA La primacía eclesiástica de Toledo en el Siglo XII (1086-1208), "Anthologica Annua", 10 (1962), pp. 11-87. MANSILla, Orígenes de la Organización Metropolitana en la Iglesia Española, "Hispania Sacra", 12 (1959), pp. 255-91.

${ }^{79}$ RIVERA, La primacía, p. 87
} 
severe papal censures for their disobedience here and the matter had perplexed Eugenius III unto his dying day ${ }^{80}$. But gradually the Papacy shifted its position. The Papacy did not wish to deal with overmighty prelates any more than with threatening Emperors, and the willingness of many Peninsular rulers and Churchmen to recognize the supreme judicial power of the Pontiff, left Toledan claims looking generations behind. The Papacy opted for considering the primacy as an essentially honorific title, which increased dignity but not jurisdiction. Innocent was happy for Toledo to keep its place in the sun just provided it left nobody else in the shade ${ }^{81}$.

Don Rodrigo saw things differently. Before Las Navas, Innocent had said that the Primacy issue would be debated at the fitting time and this was now fulfilled ${ }^{82}$. Rodrigo's performance only survives to us from a manuscript of 1253 that is Toledan in origin and sympathies. The Archbishop's opponents are given little opportunity to speak, but the report is probably a substantially authentic though slightly improved version of Rodrigo's orations ${ }^{83}$. According to the report after delivering a sermon in six languages which gained the admiration of all and the like of which had not been heard since Apostolic times, Rodrigo, in full consistory issued his complaints against Braga, Compostela, Tarragona, and Narbonne, producing and reading some of the many privileges that the Papacy had granted Toledo (though not necessarily the ones most supportive to his case). Rodrigo then attacked Braga and Compostela in turn; aided by the frescoes on the walls of the Lateran, Rodrigo described the treachery of the Bragan see that had bred Burdinus, the anti-pope Gregory VIII, who had attacked the Roman Church 'quæ omnium ecclesiarum mater est et magistra'. On Compostela, Rodrigo reflected that its antiquity went back all of ninety-one years and it had been raised to metropolitan rank while Mérida was under the Saracens and because there was pilgrim devotion since Santiago's body was believed to be buried there. Toledo, on the other hand, really was Apostolic since it was founded by Eugenius, the disciple of Saint Paul. Moreover, it was dedicated to the Virgin Mary who remained with Christ to the Cross and the

\footnotetext{
${ }^{80}$ RIVERA, La primacía, pp. 24-5, 80 and passim.

${ }^{81}$ RIVERA, La primacía, pp. 55, 87; FOREVILLE, Latran $I V$, pp. 263-5; Robert BENSON, The Bishop-elect: a study in Medieval ecclesiastical office, Princeton University Press, 1968, p. 168.

${ }^{82} M D H I$, no. 455, pp. 482-3; MPL, 216, 423; POTTHAST, 4258.

${ }^{83}$ MANSI, 22, 1071-5; LINEHAN, History and the Historians, pp. 330-1; Foreville, Latran, p. 264; Achille LuChaire, Le Concile de Latran, Paris, 1908, pp. 32-38.
} 
Sepulchre (the implication being that Santiago did not). If the Virgin's bones were in the Cathedral at Toledo, Rodrigo asserted, they would not suffer the disrespect of being trampled over by pilgrims like the supposed Santiago at Compostela ${ }^{84}$.

Archbishop Pedro Muñiz protested that Toledo had no primatial rights but if Rodrigo had not exhausted his invective on the scholarly prelate, he would now find bringing the performance to a crescendo somewhat difficult. The consistory was not quite full after all. The Archbishop of Tarragona was not present. Espàreg clearly did not think that such a matter called for his attention. Nor, it would appear, did the bishops of Barcelona, Gerona, or Urgell ${ }^{85}$. Nor did Bishop Hispan (though he may have been ill $)^{86}$. And if Rodrigo wished to launch into Narbonne, Amalric was not there either (he explained to everyone the next day that he had not been cited in the case $)^{87}$. Innocent would have been spared any arguments over seats since Guillem de Tavartet, bishop of Vic, was the sole representative of the East of the Iberian Peninsula to speak in the Primacy debate ${ }^{88}$. If the Toledo manuscript is accurate here, Guillem responded on behalf of his absent colleagues (seemingly in as brief and curt a manner as possible) that

\footnotetext{
${ }^{84}$ MANSI, 22, 1071-5; LINEHAN, History and the Historians, pp. 328-30; FOREVILLE, Latran, p. 264; FOREVILLE, L'Iconographie du XIIe, Concile Oecuménique: Latran IV (1215), in Mélanges René Crozet, 2 vols., Poitiers, 1966, 2, pp. 1125-7; Carl ERdMANN, Mauritius Burdinus (Gregor VIII.), "Quellen und Forschungen aus italienischen Archiven und Bibliotheken", 19 (1927), 212-7; BOLTON, A show with a meaning, pp. 60-1; Gerhard LADNER, I mosaici e gli affreschi ecclesiastico-politico nell'antico palazzo Lateranense, "Rivista di Archeologia Cristiana", 12 (1935), pp. 265-92.

${ }^{85}$ MANSI, 22, 1075; RIVERA, Personajes Hispanos Asistentes, p. 345, points to the absence of these prelates on that day (and the bishops of Burgos, León, Salamanca, Avila, and possibly Mondoñedo); LinEHAN, Spanish Church, p. 35, on the basis of the Toledan accounts published by RIVERA, insists on Espàreg's absence not only that day but from the Council altogether, but the Zurich Ms. suggests otherwise, and the Toledo accounts may wish to convince us of Espàreg's apathy even beyond its actual measure. See LUCHAIRE, Un document retrouvé, "Journal des Savants", 3 (1905), p. 562.

${ }^{86}$ RIVERA, Personajes Hispanos Asistentes, p. 342; VL, 3, p. 37 (Hispan died on 11 December 1215).

${ }^{87}$ MANSI, 22, 1075: 'Narbonensis qui tunc aberat, sequenti die in pleno consistorio respondit, se ad hoc citatum non fuisse'.

${ }^{88}$ MANSI, 22, 1075: 'Pro Tarraconensi autem archiepiscopo, qui non aderat, respondit episcopus Vicensis suffraganeis eius, pro se et pro aliis suffraganeis eius absentis'. On the fraught problem of episcopal seating arrangements, see SOMERVILLE, Pope Alexander III and the Council of Tours, p. 25.
} 
the Archbishop of Toledo was not the primate and they did not owe him any obedience $^{89}$.

That reflected political reality in 1215 and 1253. Castile had long since recognized the independence of the Crown of Aragon and not all the words of Rodrigo could alter that essential fact ${ }^{90}$. Innocent confirmed Toledo's primatial dignity in April 1216, but what did it really mean? ${ }^{91}$. As when Innocent silenced Siegfried, archbishop of Mainz, so when Espàreg absented himself from the assembly, the Fourth Lateran Council announced an end to the old order and a waning of empires. ${ }^{92}$

\section{THE DISPOSSESSION OF RAYMOND VI}

On Saturday, 14 November, the questions concerning the possession of the lands of Toulouse and other lands in the South of France were debated $^{93}$. Most of the leading participants in the drama were present at the Council. Peter of Benevento, Robert de Courçon, Amalric, Foulques of Toulouse, and the majority of the southern French bishops were there. The two Counts of Toulouse, the Counts of Foix and Comminges, the Aragonese envoys (representing James), Raymond de Roquefeuil (representing young Trencavel), and Guy de Montfort (representing Simon) all prepared to fight their corner ${ }^{94}$. The Giessen text also records that Eleanor of Aragon, wife of Raymond VI, was present (a matter of interest to the author since Eleanor was sister-in-law to Frederick II) ${ }^{95}$. Was it now that Eleanor's companion, Lady Fizás, introduced into the papal palace, vested as a pilgrim, a Cathar

\footnotetext{
${ }^{89}$ MANSI, 22, 1075: 'Toletanum archiepiscopum nec esse primatem, nec se debere illi in aliquo obedientiam praestare'. Guillem de Tavartet, having been elected in 1195 ( VL, 7, p. 15 , pp. 241-2), was the senior bishop of the province.

${ }^{90}$ Antonio UBIETO ARTETA, Homenaje de Aragón a Castilla por el condado de Navarra, "EEMCA", 3 (1947-8), pp. 7-28; UBIETO ARTETA, Navarra-Aragón y la idea imperial de Alfonso VII de Castilla, "EEMCA", 6 (1956), pp. 41-82.

${ }^{91} M D H I$, no. 530, p. 564, corresponding to PotThAST, 3924; $M P L, 216,199$. The debate 'super primatia' with Braga was re-set for All Saints, 1216 (MDHI, no. 533, p. 565; POTTHAST, 5169; THEINER, 65, no. 59).

${ }^{92}$ New Eyewitness, p. 128. 52-3.

${ }^{93}$ New Eyewitness, pp. 124-5; García Y GARCÍA, El gobierno de la Iglesia Universal, pp.

${ }^{94}$ ROQUEBERT, L'Épopée Cathare, 2, pp. 345-60.

${ }^{95}$ New Eyewitness, p. 124.
} 
deacon, whom Fizás 'adored' while the Pope said Mass?' ${ }^{96}$ It is an intriguing question but it is the land that Eleanor held in dowry that would have mattered to both her and to Innocent. The Aragonese envoys may have put forward her case, saying that Eleanor was always a good Catholic and there was no reason to dispossess her ${ }^{97}$. The matter does not appear in the fullest surviving account of the debate, which comes from the anonymous continuator of the Chanson de la Croisade Albigeoise ${ }^{98}$. The work is heavily biased in favour of the South and it is unlikely that Innocent treated suspected enemies of the Church with quite the gushing bonhomie the author suggests. Yet that Innocent was sympathetic to Raymond VI's plight is attested by Guillaume le Breton, and even Vaux-de-Cernay indicated that some members of the Council were against Montfort ${ }^{99}$. The only problem with the Chanson is the tone; the work is otherwise invaluable. The poet was most probably a witness to most of the events that he described and his extraordinarily intimate knowledge of the personalities and politics involved is entirely in accord with what we know of these episodes independently of him $^{100}$.

According to the Chanson, Innocent was initially impressed by Raymond VII of Toulouse and indicated that since Raymond VI was not a heretic he should not lose his lands to Montfort. The Comte de Foix then made a speech informing the assembly that he had personally never been an abettor of heretics, that there was no good reason to deny Raymond VII his inheritance, that everybody had suffered unduly at Montfort's hands, and that he himself had faithfully delivered to the Church the castle of Foix as had been asked of him. Cardinal Peter of Benevento then confirmed that the castle had been delivered to him, after which bishop Foulques of Toulouse gave an impassioned philippic against Raymond-Roger, whom he considered

\footnotetext{
${ }^{96}$ Ventura, El Catarismo en Cataluña, "Boletín de la Real Academia de Buenas Letras de Barcelona", 28 (1961-2), p. 114.

${ }^{97}$ PotThaST, 5009; HGL, 8, 681; RHGF, 19, 598.

${ }^{98}$ Chanson, 2, pp. 40-89.

${ }^{99}$ Gesta Philippi Augusti, ed. H.F. DELABORDE in his Oeuvres de Rigord et de Guillaume le Breton, Paris, 1882-5, c. 216, p. 306; VAUX-DE-CERNAY, c. 572, p. 216.

${ }^{100}$ For its value, see BOLTON, $A$ show with a meaning, p. 60; BELPERRON, La Croisade contre les Albigeois, p. 360; ROQUEBERT, L'Épopée Cathare, 2, p. 354: 'sa parfaite connaissance du contexte psychologique et politique du moment nous interdit de penser qu'il a pu, a posteriori, reconstituer du tout au tout les débats. Tout se passe même comme s'il avait été chargé d'une mission bien précise: écouter -et noter au besoin- ce qui allait se dire'.
} 
guilty of all manners of heretical crimes. Foulques and Foix then exchanged accusations and insults, with others joining in. Innocent calmly responded that Foix would be given justice if what he said was verified. Raymond de Roquefeuil received the same promise when he got up to defend the rights of Trencavel. Then Innocent retired to the papal gardens to relax and collect his thoughts, only to find himself being followed by a group of crusading prelates. These men suggested to Innocent that they were ruined if the lands were returned to their former lords. Innocent expressed his unhappiness that Raymond VII for no just reason should be deprived of his inheritance, while he accepted that Montfort should retain the lands captured from heretics except those that pertained to widows and orphans ${ }^{101}$.

When the Council re-assembled, Foulques again spoke up, clearly outraged that by this piece of sophistry Innocent would be depriving Montfort of lands that he rightfully held. The archbishop of Auch confirmed that this would be an injustice and a disaster. Cardinals, bishops, and archbishops, numbering three hundred, argued that they had preached and explained to the people that Raymond VI was a bad man and thus could not keep his land. The archdeacon of Lyon then spoke up in Raymond's defence and Innocent added that it was the duty of the Church to open its arms to repentant sinners. Amalric backed Innocent up, advising him to judge and govern without fear and not to give in to pressure. Innocent then asked why the lands should be given to Montfort if Raymond VI was penitent. Master Thédise responded that Montfort's good faith in pursuing heresy and defending the Church ought to make him the possessor of the land. Innocent responded that Montfort seemed to persecute everyone and complaints about him reached Innocent all the time. But the general clamour was in favour of Montfort whose achievements were enumerated. But Innocent rejoined that even if Raymond VI was condemned, why should his son lose his inheritance? The prelates were unmoved and demanded that the country should go to Montfort. Finally, the archbishop of York, representative of King John of England, pointed out that the lands that Raymond VII held through his mother Joan's dowry must remain to Raymond since the agreement of the dowry had been confirmed by the Roman Curia itself. The

\footnotetext{
${ }^{101}$ Chanson, 2, pp. 42-61. The final point being that because Montfort had left so many widows and orphans, he would not now be left any land.
} 
abbot of Bewley indicated that this was the wish of Raymond's uncle, King John, and Innocent affirmed his support for the viewpoint of his vassal ${ }^{102}$.

That was how the Chanson saw the debate. Perhaps Innocent, neither certain of where justice was in the case nor desirous to aggravate his episcopal colleagues, considered it advisable to let the majority will prevail here in return for most of his designs succeeding elsewhere. The sentence of the Council was read in the closing session of 30 November. Firstly, the seventy dogmatic canons were unanimously adopted and a general Peace promulgated as a prelude to the new crusade. Then, following the decision on the imperial question in favour of Frederick, Raymond VI heard his fate ${ }^{103}$. The decree was published on 14 December. Raymond was found culpable of complicity with heretics and protection of routiers and was perpetually deprived of his property, being left only a small annual pension. Eleanor, since she was known to be a good Catholic, was to keep all the lands of her dowry, on condition that she administered them according to the orders of the Church, without prejudice to the affair of the Peace and Faith, or she could alternatively receive a suitable compensation for them. All the lands conquered from the heretics were remitted and conceded to Montfort. The remainder of the country was to be entrusted to capable people until Raymond VII came of age and showed that he deserved to retain it ${ }^{104}$. The County of Foix needed a supplementary inquiry. On 21 December, Innocent instructed the bishop of Nimes and the archdeacon of Elne to look into the complaints of the Comte de Foix and move towards returning to him the castle of Foix itself ${ }^{105}$. When the archdeacon died, Innocent appointed Ramon de Palafolls, bishop of Gerona, to take his place as judge ${ }^{106}$.

\footnotetext{
${ }^{102}$ Chanson, 2, pp. 62-77; cf. New Eyewitness, pp. 124-5. See also ROQUEBERT, L'Épopée Cathare, 2, pp. 361-75; VENTURA, Pere el Catòlic, pp. 251-8; FOREVILLE, Innocent III et la France, p. 330; CHENEY, Innocent III and England, pp. 395-6; Helene TILlmANN, Pope Innocent III, North-Holland, 1980, pp. 238-40.

${ }^{103}$ New Eyewitness, pp. 125, 141-2; VAUX-DE-CERNAY, chs.570-2, pp. 215-6; RYCCARDUS DE SANCTO Germano, Chronica, "Rerum Italicarum Scriptores", ed. C.A. GaRUFI, 1937, p. 40, note 1; Chanson, 2, pp. 78-9; GARCÍA y GARCía, El gobierno de la Iglesia Universal en el Concilio IV Lateranense de 1215, pp. 52-3.

${ }^{104}$ PotTHast, 5009; HGL, 8, p. 681; RHGF, 19, pp. 598-9.

${ }^{105}$ POTTHAST, 5014; HGL, 8, p. 682; RHGF, $19,600$.

${ }^{106}$ PoTTHAST, 5113: $M D H I$, no. 551, p. 576; $H G L, 8,684$.
} 


\section{THE ReCONCILIATION OF THE MONTCADA}

While Innocent had compromised a little, these decisions spelt the realistic end to the wider Languedocien ambitions of Aragon. The consolidation of the Crown was now the prime objective of the envoys. Probably the first matter to be dealt with was the reconciliation of Guillem Ramon de Montcada, whose lands and great family was crucial in the stability of the government during the minority. It was twenty-one years since Guillem, disgruntled and alienated from Alfonso II's circle, had brutally done to death Archbishop Berenguer de Vilademuls and so appalled Celestine $\mathrm{III}^{107}$. The good government of Béarn, with the traditional pressure on the Montcada family from the bishops of Vic, drove Guillem finally to seek absolution ${ }^{108}$. After making his will in September 1215, Guillem set off to the 'threshold of the Holy Apostles Peter and Paul' ${ }^{109}$.

His case was delegated by a busy Innocent to three figures of the first rank, Cardinals Nicholas of Tusculum, Pelayo of Albano, and Ugolino of Ostia (the future Gregory IX) ${ }^{110}$. After hearing Guillem's confession that, 'suadente diabolo', he had killed Berenguer, the Cardinals, with the authority of the Pope, absolved him, enjoining upon him a penance in proportion to his crime. On returning home, Guillem was instructed to go as soon as possible to Tarragona and walking through the city, bare-foot and semi-naked, he was to be whipped at the entrance of each church of the city

\footnotetext{
${ }^{107}$ The famous letter of Celestine III to the suffragans of Tarragona describing the assassination is printed in VL, 19, pp. 305-8; on the background to the case, the legend, and the curse, see the study of M. COLL I ALENTORN, La Llegenda de Guillem Ramon de Montcada, Barcelona, 1958, and SHIDELER, Montcadas, pp. 123-8.

${ }^{108}$ ShIDELER, Montcadas, p. 139; ENGELS, Die weltliche Herrschaft des Bischofs von Ausona-Vich, 889-1315, "Gesammelte Aufsätze zur Kulturgeschichte Spaniens", 24 (1968), p. 20; Paul FREEDMAN, The Diocese of Vic: Tradition and Regeneration in Medieval Catalonia, New Brumswick, NJ, 1983, passim; J. GUDIOL I CUNILL, Les bregues sobre lo senyoríu de Vich en temps del rey En Jaume I, "CHCA", 1 (1908), i., p. 194; SHIDELER, Les tactiques politiques des Montcada, seigneurs de Vic du début du xiiie siècle, "Ausa", 9 (1981), pp. 329-42. Also on Vic versus Montcada at the time of the Council, see, tantalisingly, $M D H I$, nos. 540-1, p. 569; POTTHAST, 5205-6; THEINER, 66, nos. 95-6.

${ }^{109}$ SHIDELER Montcadas, p. 140.

${ }^{110} V L, 19,304-5$; SHIDELER, Montcadas, p. 140; COLL I ALENTORN, Llegenda, p. 47, puts the absolution in mid-June 1216. Though he argues from the absence of documents relating to the Viscount in Catalonia at that time, there are no known Catalan document's witnessed by Guillem for the last months of 1215 , and December 1215 would fit in with the will, the rubrics, and the Cardinals presence in Rome, all noted above.
} 
by any priests available. Then Guillem was to do homage to the Archbishop and the chapter and pay to them an annual rent of twenty pounds of silver. Moreover, Guillem was to take the Cross, and go to the Holy Land for five years, with two hundred knights and thirty artillerymen and archers. Unless crusading, throughout his life he was to undergo severe bread and water fasts during stipulated periods, and give gifts to the poor. Guillem was always to wear a hair shirt, unless performing his conjugal duties (since his wife, Guilleuma, had left him by 1202 , it was probably Guillem's concubine, Navarra, who benefited from the Church's decision here). Finally, Guillem could redeem his Monday or Wednesday fasts by helping five paupers, and the Cardinals in advance ratified alternative valid penances made by other prelates ${ }^{11}$.

We do not know how much of this penance was carried out. Coll i Allentorn has pointed to Guillem's presence in Tarragona from February to April 1216 and reasonably suggested Guillem would have done homage to Archbishop Espàreg then. Equally, Guillem certainly did not go on crusade to the Holy Land ${ }^{112}$. But it was the act of submission rather than fulfillment of the penance that really mattered. The Montcada could thus retake his invaluable place in Catalan government and the Pope who had in his youth traveled to the tomb of Becket again triumphed over the enemies of ecclesiastical liberty ${ }^{113}$.

\section{The Protection of the ORPhan King}

Perhaps the death of Bishop Hispan on 11 December altered the balance of the negotiations directly concerning James. Certainly, the remaining envoys argued for measures from the Pope that very much increased their and their allies powers in the Kingdom, neutralised Ferdinand, decreased the influence of Sanç, and further diminished the opportunities for continuing the fight in the North. In a series of letters dated

\footnotetext{
${ }^{11} V L, 19$, pp. 304-5; Coll I AlEntorn, Llegenda, p. 47; Shideler, Montcadas, p. 140, and p. 127 , note 50 (for concubine).

${ }^{112}$ ACA, perg. Jaume I, 53, 58; COLL I ALENTORN, Llegenda, pp. 46, 48; SHIDELER, Montcadas, p. 140; MARCA, Histoire de Béarn, pp. 561-2.

${ }^{113}$ MACCARRONNE, Innocenzo III prima del pontificato, "Archivio della Società romana di storia patria”. 66 (1943), p. 78.
} 
23 January 1213, Innocent sought to consolidate and develop the position of the government during the minority. Addressing all the nobles of Aragon and Catalonia, Innocent set forth the grounds for his intervention. The care of any orphan concerned the Pope, but his sollicitude was greatest when concerned with those who especially looked to the Apostolic See for help (qui specialius ad apostolicam sedem spectant), and particularly when talking of a prince who was responsible for many people it was fitting for the Pope to provide for the King's own position and the health and increase of his subjects. For these reasons Innocent was intervening in the case of James so the procurator Sanç could more usefully govern the land. Since it had been indicated to Innocent by men who desired the good of the kingdom (qui regni bonum diligunt) that the single authority of Sanç had proved insidious to some, Innocent now provided the Procurator with deputy councillors: in Aragon, García Frontín, bishop of Tarazona, and the noblemen Eiximen Cornel and Pedro Ahones; in Catalonia, Espàreg, archbishop of Tarragona, and the noblemen Guillem de Cervera and Guillem de Cardona, and the Master of the Templars in Ispania, Guillem de Montrodon. The Count and the council, or the greater part of them when all were not able to convene, were to respond for James if the King of Navarre or the King of Castile or anybody else brought business that needed serious response. Beyond this, Innocent ratified many of the decisions of his legate Cardinal Peter, confirming the division of the honores in Aragon, ordering the observation of the Peace in Catalonia and the statutes approved at Lleida, as well as the truce with the Saracens, and reiterating the demands to Jews and Saracens concerning the redemption of pledges ${ }^{114}$.

Innocent then addressed himself to all the men of the castles and towns of Aragon and Catalonia. Innocent indicated that the welfare of the people (salus populi) was dependent upon the strength of the position of their lord and therefore it was fitting for him to intervene to help and advise James's government. Since it had been reported to Innocent that to the detriment of the Kingdom much of James's land had been pledged, and since James was not of an age whereby he could remedy the situation himself, Innocent asked and advised that, as a meritorious act, they provide aid, in the hands of the Master of the Templars, for the redemption of the King's

${ }^{114}$ ACA, Butlles, Innocent III, leg. 3, no. 25; $M D H I$, no. 537, pp. 566-8; SANPERE, Minoría de Jaime I, pp. 609-10; POTTHAST, 5181; THEINER, 65, no. 66; SOLDEVILA, Els primers temps, pp. 95-101. 
pledges $^{115}$. Similarly, Innocent instructed all the men of Montpellier that on all financial and legal matters concerning the orphaned James they were to deal with Guillem de Montrodon ${ }^{116}$.

Though our view is obscured by the loss of the Registers for these years and the difficulties of interpreting copies of letters amended for the interests of later ages, Innocent certainly took a number of further steps to help James. Probably in May 1216, Innocent directed his attention to Abbot Ferdinand of Montearagón. Innocent expressed himself appalled that Ferdinand was so lacking in natural affection for his nephew that in his blindness and ambition he had sided with the cities of Zaragoza, Huesca, and Jaca and other nobles of the Kingdom to conspire against the King. He was immediately to desist from his activities and his problems could be argued out at the Curia by the Feast of All Saints next ${ }^{117}$. At the same time, Innocent informed the people of Zaragoza, Huesca, and Jaca, that he had received complaints suggesting they had broken the oath they swore before the Cardinal-legate at Lleida. Since James was under the protection of the Apostolic see and his Kingdom paid a census to the Roman Church, it was Innocent's place to warn them that they must cease from their rebellions against the King. If they did not do so then the Archbishop of Tarragona, the bishop of Lleida, and the abbot of Poblet, would compel them through ecclesiastical censure ${ }^{118}$. Some time between February and July 1216, Innocent instructed Philip Augustus that James, as heir to the domain of Montpellier, should not be attacked by him, nor should he allow others to attack James ${ }^{119}$. To Count Sanç, it was written that he should carry out the office of Procurator committed to him according to the instructions of the letters of the Cardinal-legate ${ }^{120}$, while the barons of Aragon-Catalonia were ordered to observe inviolably the truce with Montfort ${ }^{121}$.

\footnotetext{
${ }^{115}$ ACA, Butlles, Innocent III, leg. 3, no. 26; ed. BISSON Finances, App. 1, p. 375; cited $M D H I$, no. 538, p. 568; POTTHAST, 5182; SANPERE, La Minoría de Jaume I, p. 606; SOLDEVILA, Els primers temps, pp. 86-7.

${ }^{116} M D H I$, no. 539, p. 568; PotThaST, 5183; SANPERE, La Minoría de Jaume I, p. 606; SOLDEVILA, Els primers temps, p. 87.

${ }^{117}$ Palacios Martín, La coronación, p. 302.

${ }^{118}$ Palacios Martín, La coronación, pp. 302-3.

${ }^{119} M D H I$, no. 556, p. 581; POTTHAST, 5220; MPL, 216, 995.

${ }^{120} M D H I$, no. 565, p. 583; POTTHAST, 5314; TheINER, 70, no. 211.

${ }^{121} M D H I$, no. 554, p. 581; POTTHAST, 5214; THEINER, 67, no. 119.
} 
Sanç would harass the North so long as he had power to do so ${ }^{122}$. Montfort, in the final irony, struggled with Amalric, the Count physically attacking the prelate, the prelate excommunicating the Count ${ }^{123}$. Innocent had given himself over to his final dream, of an Italian-controlled Crusade. To his last day, the recovery of the Holy Land remained his chief desire. He preached, attacked those who did not fulfil their vows or those who stopped them from so doing, organized transport, appointed the legates, and decided on those measures for clerical taxation that the Church of Aragon in particular would be so reluctant to accept. Holding to his vision of a universal society of ordered peace, Innocent traveled north to negotiate an accord between Pisa and Genoa ${ }^{124}$. His last contacts with the affairs of Catalonia were probably the privileges of protection which he granted to the monasteries of Santa Maria d'Estany (Vic) and Sant Cugat (Barcelona) on 31 May and 10 June 1216 respectively, and, with Aragon, in the protection to the hospital of Santa Cristina de Somport (Huesca) on 4 June, all while at Perugia ${ }^{125}$. There he remained, dying of a fever on 16 July, appropriately the date of Las Navas de Tolosa, and there Jacques de Vitry found him, his corpse plundered by robbers, left naked and decomposing, and causing the preacher to reflect on how transitory and vain the deceiving splendours of this world are ${ }^{126}$.

But Innocent's reputation would not be left naked in Perugia. The orphan boy grew up to be King James I, el conquistador, the mightiest of all the sons of the Reconquista. And James did not forget. In about 1244, in the first section of his autobiography, the King looked back to those troubled

\footnotetext{
${ }^{122}$ Ventura, Pere el Catòlic, pp. 259-93; SANPERE, La minoría de Jaume I, pp. 633-94; SOLDEVILA, Els primers temps, especially c. 7; SHIDELER, Montcadas, pp. 142-5.

${ }^{123}$ RoQuEBERT, L'Épopée Cathare, 2, pp. 390-3.

${ }^{124} J a m e s$ POWELl, Anatomy of a Crusade 1213-1221, Philadelphia, 1986, pp. 1-120; FREEDMAN, Two Letters of Pope Honorius III on the collection of ecclesiastical revenues in Spain, Römische Historische Mitteilungen, 32-3 (1990-1), pp. 37-40; LINEHAN Spanish Church, p. 19.

${ }^{125}$ (Estany) ACB, perg., 3-2-181; (Sant Cugat) ACB, perg., 3-2-182; (Somport) $M D H I$, no. 553, pp. 578-81.

${ }^{126}$ Lettres de Jacques de Vitry, ed. Robert HuYgens, Leiden, 1960, no. 1, pp. 73-4: 'Post hoc veni in civitatem quandam que Perusium nuncupatur, in qua papam Innocentium inveni mortuum, sed nundum sepultum, quem de nocte quidam furtive vestimentis preciosis, cum quibus scilicet sepeliundus erat, spoliaverunt; corpus autem eius fere nudum et fetidum in ecclesia relinquerunt. Ego autem ecclesiam intravi et oculata fide cognoví quam brevis sit et vana huius seculi fallax gloria'; Philipp FUNK, Jakob von Vitry: Leben und Werke, Hildesheim, 1973, p. 39.
} 
times, and recalled that Innocent had been a good clerk in the learning of the world, and, from the time of writing, the best apostle of the Roman Church for a hundred years ${ }^{127}$.

James had cause to say so. Certainly, the auctoritas of the Cardinallegate and the Pope had protected James from threats within and outside the realm, and probably saved not only his throne but also his life. Certainly, the legate's instructions and the alterations made by the Pope to meet the problems that became clearer as time went on, had a profound and lasting affect on government in the Crown ${ }^{128}$.

The Roman see had gained an unprecedented influence in Aragon and her voice extended to every magnate, town, and castle. Innocent had stretched his intervention in the temporal dominion to the making of laws and the raising of revenues. It must be pointed out that he never did so by virtue of some claim to supreme overlordship inherent in the office of the Vicarius Christi, but rather because a special relationship existed through the census given to the Roman Church and because he was asked to intervene by the nobles themselves. The combination of the willfully conceded protection of the realm and the generally accepted duty that the Pope held towards miserabiles personae, allowed Innocent to extend his power in a radical manner while appearing, to the untrained eye, conservative.

Was it power for power's sake? No, never. Christ had given power to Peter for the cura et sollicitudo of the whole of mankind and as the Pope was one with Christ in blessed Peter so it was his duty to rule in a manner that diffused grace to his people and prepared them for the coming struggle against Anti-Christ. The maintenance of order and peace always remained decisive in the unification, purification, and sanctification of the Christian people.

Desire it was, and reality is severe. Shrewd operators could manipulate legate and Pope, decisions were often wrong or outdated, authority was by no means always respected, and administratively the communications system to improve matters did not exist. The Cardinal-legate could act as a dictator (in something like the original sense) but he could not be more. It was uncle Espàreg who held James aloft at Lleida, and thus it

\footnotetext{
${ }^{127}$ Llibre dels Feits, c. 10, p. 47.

${ }^{128}$ Bisson, The Medieval Crown of Aragon, pp. 75-6; PALACIOS Martín, La Coronación, passim; FRIED, Päpstliche Schutz, pp. 235-59: LlADONOSA, Història de Lleida, 1, pp. 41-2.
} 
was that the affairs of the Counts of Barcelona ultimately remained, as they had always been, within the family.

\section{RÉSUMÉ}

Cet article examine le rapport entre la Papauté et Aragon-Catalogne pendant la période 1213-1216. Après la mort du Roi Pierre II (12/9/1213), la Couronne, généralement une alliée étroite de Rome, était face à une crise très sérieuse. Comment ont réagi le Pape, Innocent III, et son envoyé, le Cardinal Pierre, à cette crise, et comment ils ont protégé le roi nouveau, Jacques I ? La réponse révéle beaucoup au sujet de la étendue réelle et des buts du pouvoir pontifical, et ajoute encore du renseignement au sujet des années formateux du grand Roi Jacques I. De toute évidence, Innocent III, avec les arguments normaux, a augmenté sa intervention à l'intérieur du domaine temporal à une mesure sans précédent, mais, à la fin, ses buts et les mécanismes de pouvoir ont limité sa influence.

\section{SUMMARY}

This article examines the relationship between the Papacy and Aragon-Catalonia during the period 1213-1216. After the death of King Peter II (12/9/1213), the Crown of Aragon, traditionally a close ally of Rome, was plunged into a grave crisis. A study of how the Pope and his legate, Cardinal Peter of Benevento, react to this crisis, and protect the new King, James I, tells us much about the actual extent and objectives of pontifical power, as well as adding much information on the early years of the great Catalan ruler. It is evident that the Pope, using traditional justifications, stretched his intervention in the temporal dominion to an unprecedented extent, but ultimately the Pope was limited both in his objectives and by the actual mechanisms of power. 